\title{
Crime
}

\section{Jean-Baptiste Fleury}

\author{
Université de Cergy-Pontoise \\ jbfleury@gmail.com
}

This material has been published in Society on the Edge: Social Science and Public Policy in the Postwar United States, edited by Philippe Fontaine and Jefferson Pooley (https://doi.org/10.1017/9781108765961). This version is free to view and download for private research and study only. Not for re-distribution or re-use.

Jean-Baptiste Fleury. "Crime" In Society on the Edge: Social Science and Public Policy in the Postwar United States, edited by Philippe Fontaine and Jefferson D. Pooley, 258-289. Cambridge: Cambridge University

Press, 2020. https://doi.org/10.1017/9781108765961.007 


\section{Crime}

Jean-Baptiste Fleury, Université de Cergy-Pontoise, jbfleury@gmail.com

doi

IN 1968, BRUSHING aside almost fifty years of social scientific research, Gary Becker wrote that "a useful theory of criminal behavior can dispense with special theories of anomie, psychological inadequacies, or inheritance of special traits and simply extend the economist's analysis of choice." ${ }^{1}$ The remark illustrates the confidence displayed at the time by an increasing number of economists investigating problems traditionally considered outside their domain of expertise. But Becker also hinted at a major intellectual change: As crime became untethered from other social issues (including poverty and race) in the public discourse and policy interventions, its study gradually turned away from the socioeconomic causes of criminals' behavior so dear to sociologists and social psychologists. Social scientists were now focusing on crime's efficient management, welcoming the contributions of economists, political scientists, and operations researchers, which seemed better suited to the pressing need to rationalize public policies.

In the preceding decades, sociologists and social psychologists had helped establish a social scientific consensus, one that relegated onceprevalent biological explanations to quackish obscurity. Although these postwar social scientists failed to develop a fully integrated approach, they successfully positioned crime and delinquency as enfolded within the broader dynamics of deviance, urbanization, family life, and subculture formation. They located the causes of criminal behavior, for the most part, in the social environment. By the early 1960s, their environmental approach grounded a number of initiatives that, with the support of federal agencies and philanthropic foundations, sought to integrate "delinquents" into their communities by fostering empowerment and legitimate opportunities, culminating in Lyndon Johnson's Wars on Poverty and Crime.

Yet these theories would soon be called into question, as public attention shifted to "law and order" in the decade's second half, in the wake of a crime-rate surge and social unrest in the country's urban cores. The uptick in crime, together with the racialized visibility of the riots, was seized by conservative politicians to drive a wedge in the electorate and to discredit Great Society welfare policies. The new political attention on crime as a standalone problem led, indirectly, to the creation of cross-disciplinary programs bringing together economists, operations researchers, legal scholars, psycholo- 
gists, sociologists, and political scientists under the "criminal justice" label. These programs forged a distinctive approach to crime as an isolated problem primed for rational management. The new schools and departments of "criminal justice," in other words, incubated a social scientific outlook that prioritized cost-effectiveness, rational behavior, and deterrence-_"systems of crime control and the broader political economy." 2 The public policy landscape, in turn, largely shifted to street-crime prevention, leading to a revival-mere decades after their decisive repudiation —of biological modes of explanation.

\subsection{Carving Out a Place for Social Scientists}

In the interwar era, sociologists, psychologists, and legal scholars successfully established the primacy of environmental factors over biological determinants in the explanation for criminal behavior. The belief that specific morphological, physiological, and mental traits engendered criminal behavior had indeed grounded the analyses of European "criminal anthropologists" during the second half of the nineteenth century. ${ }^{3}$ This movement was epitomized by the so-called Positive School and its notorious members Cesare Lombroso and Raffaele Garofalo (who coined the term "criminology"). Originally influenced by evolutionary theory, they traced the "criminal type" to lags in evolution. ${ }^{4}$ By the mid-1910s, however, a number of landmark studies by physicians and psychiatrists had expanded the range of causal factors to family dynamics and economic or social conditions. ${ }^{5}$ In Great Britain, Charles Goring's large-scale 1913 statistical study of British inmates authoritatively rejected the Positive School's notion of a "criminal type." 6 In the United States around the same time, William Healy warned against any monocausal theory. A physician and a psychologist trained in psychoanalysis, Healy stressed that delinquents had to be considered in their complexity, with environmental and psychological factors, such as weak parental control, poverty, mental conflict and repression, and/or "abnormal" sexuality, taken into account.7

Healy's work was widely acclaimed and paved the way for the development of an approach that sought to identify the multiple factors that contribute to crime, and estimate their relative weight or predictive powers. Among the prominent adopters of this approach were Sheldon and Eleanor Glueck, Harvard legal scholars deeply influenced by Healy's work. ${ }^{8}$ Beginning with the widely praised Five Hundred Criminal Careers in 1930, the Gluecks regularly published detailed longitudinal studies of criminals or delinquents that won massive influence within criminology. They underlined how social forces-such as economic or class conditions-were intertwined with
${ }^{2}$ Laub, "Life Course of Criminology in the United States," 1.
${ }^{3}$ Davie, "Impact of Anthropological
Criminology."

${ }^{4}$ Garofalo, La criminologie.
${ }^{5}$ Garofalo considered education and economic factors but discarded their importance in motivating criminal behavior. It appears that Lombroso's school was portrayed as the founder of modern criminology by early twentiethcentury criminologists. Yet, the Positive School's influence during the early twentieth century may have obscured previous works, for instance those of Adolphe Quételet or André-Michel Guerry, which already emphasized environmental factors. See Lindesmith and Levin, "Lombrosian Myth in Criminology."

${ }^{6}$ Goring, English Convict, 15-18. Skepticism about the "positive school" approach had been mounting at the end of the nineteenth century, especially in Great Britain. For an account of the context of late nineteenth-century British criminology, see Davie, "Impact of Anthropological Criminology."

${ }^{7}$ Healy, Individual Delinquent, 30-31, 24-29.

${ }^{8}$ Sampson and Laub, Crime in the Making, 33-34. 
individual-level factors, like a broken home, age, intelligence, psychological dysfunction, school misconduct, parental supervision, or working habits. Two decades after their first book, criminologists were still debating which factors were decisive, with the Gluecks somewhere in between the two extreme positions: one that emphasized biological causes (e.g., the anthropologist Earnest Hooton) and the other that stressed environmental factors (as with Chicago School sociologists).

Ernest Burgess, a leading Chicago School figure alongside Robert Park, was also influenced by Healy's use of case studies, inductive techniques, and psychoanalysis, but argued that his analysis left little room for the study of social forces and the diagnosis of the social pathology of crime. ${ }^{9}$ Although Burgess' own attempt to build predictors of "expectancy rates" of parole violations-which became a fast classic in the field-relied quite significantly on individual-level factors, the influential work of his protégés pointed to broad social forces, instead, as the major causes of delinquency. ${ }^{10}$ Clifford Shaw's and Henry McKay's work, from the late 1920s on, linked crime rates to social factors like residential instability, ethnic heterogeneity, and poverty, while treating "under the roof" variables like broken families as insignificant. ${ }^{11}$ This first ecology of delinquency, in effect, applied Park and Burgess' portrayal of the city as a natural organism, in which social and cultural equilibria within specific urban areas were constantly disturbed by forces like migration, influencing in turn the geographic distribution of delinquency.

These developments had certainly benefited from late nineteenthcentury changes in the US judicial system, which introduced a distinction between adult criminals and young offenders, labeled "delinquents," who were processed through juvenile courts and separately confined in youth clinics. Healy headed the first of these clinics, the Juvenile Psychopathic Institute of Chicago, where Burgess created a sociological research section in 1926, naming Shaw as the director and McKay as a research assistant. ${ }^{12}$ In Massachusetts, meanwhile, the Gluecks maintained ties with the Judge Baker Foundation, another youth clinic that Healy codirected with Augusta Bronner shortly after his departure from Chicago in $1917 .{ }^{13}$ These institutions, host to multidisciplinary research on psychoanalysis, the biology of learning, and physical growth, provided social scientists with a reservoir of subjects on which to build empirical analyses. ${ }^{14}$

Rising public anxiety about crime in the 1920s, linked to fears over immigration, resistance to Prohibition laws, and the increasing visibility of urban gangs, spurred the work of social scientists, as many cities, states, and eventually the federal government began to focus on crime reduction. Burgess' work on parole prediction
${ }^{9}$ Burgess, "Study of the Delinquent as a Person." On the influence of Healy on Burgess, see Gitre, "Importing Freud" and Chapoulie, "Ernest W. Burgess et les débuts d'une approche sociologique." Gitre also addresses the dissemination of Freud's ideas in the social sciences (especially at Chicago) through the work of social scientists such as Hermann Adler (who replaced Healy at the Institute of Juvenile Research), Healy, Burgess, and others.

${ }^{10}$ Burgess, "Is Prediction Feasible in Social Work?" See also Bulmer, Chicago School of Sociology, 124 and Harcourt, Against Prediction.

${ }^{11}$ Shaw and McKay, "Social Factors in Juvenile Delinquency."
${ }^{12}$ Grisso, "Forensic Evaluation in Delinquency Cases," 316 and Bulmer, Chicago School of Sociology, 124.

${ }^{13}$ Glueck and Glueck, One Thousand Juvenile Delinquents, $\mathrm{i}-\mathrm{xxii}$.

\footnotetext{
${ }^{14}$ These social scientists were interested in illegal or deviant activities broadly conceived. As he focused on antisocial behavior, Healy explicitly neglected the distinction between "delinquency" and "crime." Healy, Individual Delinquent, 3.
} 
was quickly tested and adopted in the early 1930 in Illinois, where judges relied heavily on parole boards to individualize sentencing. ${ }^{15}$ Cities and states also summoned social scientists to help them build criminal surveys in the 1920 (e.g., the Gluecks in Boston), at a time when crime statistics were useless or nonexistent. By the end of the decade, many still believed that a nation-wide crime report was sorely needed. This argument was taken up by the social scientists working for President Herbert Hoover's Wickersham Commission, established in 1929 to explore law enforcement and lawlessness. In the Commission's reports, they argued forcefully for a system of statistics that would not only measure crime, but also help identify its causes and evaluate the judicial and penal systems. ${ }^{16}$ Eventually, though, Congress chose the Federal Bureau of Investigation's (FBI) Uniform Crime Index, a method that fell short of the Commission's ambitious vision and that, over subsequent decades, would be criticized time and again. ${ }^{17}$ The Wickersham report, nevertheless, granted public visibility to the multicausal approach of Shaw and McKay, Healy, and the Gluecks. The report notably concluded that environmental factors were far more important than race and immigration, and dismissed explanations for crime rooted in biology. ${ }^{18}$

The report's scientific rigor was, however, soon questioned. In their 1933 Crime, Law, and Social Science, Jerome Michael and Mortimer Adler formulated sharp criticisms that were taken seriously by the community of criminologists. In particular, they pointed to the lack of abstract and rigorous causal theory, which prevented empirical research to yield any solid generalizations and useful policy recommendations. During the second half of the 1930s, two major contributions would move the debates to a higher level of abstraction. The first one, by the Chicago-trained sociologist Edwin Sutherland, was directly related to Michael and Adler's critique. Arguably the leading criminologist in the 1930s and 1940s, Sutherland was dissatisfied with the prevailing multicausal approach. Dismissing the Gluecks' studies as mere data collecting, Sutherland believed that a proper theory required a single causal explanation, one capable of explaining any type of criminal behavior. During the second half of the 1930s, he developed a monocausal theory, "differential association," which conceptualized criminality as learned behavior through interaction with members of specific groups. ${ }^{19}$ These interactions determined how individuals interpreted their own condition, and how positive or negative attitudes toward the violation of law were transmitted to them. In 1938, a second important contribution also put the study of crime on higher theoretical ground, with the work of Robert Merton - then a graduate student at Harvard—who analyzed deviance within a functionalist framework, focusing on the interplay
${ }^{15}$ Harcourt, Against Prediction, 48, 58-59.

${ }^{16}$ US National Commission on Law Observance and Enforcement, Report on Criminal Statistics, 4.

${ }^{17}$ Gage, "Counting Crime."

${ }^{18}$ US National Commission on Law Observance and Enforcement, Report on the Causes of Crime, 16-17.

\footnotetext{
${ }^{19}$ Sutherland, Principles of Criminology.
} 
between a set of culturally defined goals and "acceptable modes of achieving these goals." Crime and delinquency, Merton argued, were the adaptive behavior of what he termed the "innovative" type, a subset of whom pursued their goals by "relinquishing the institutional [legitimate] means." This made crime and delinquency "culturally oriented if not approved" responses to social circumstances. ${ }^{20}$

By the 1940s, then, social scientists had developed strong theoretical arguments to discredit the role of biological factors for crime. Sutherland's work went a bit further: His rejection of multiple causation extended to multidisciplinary analysis, and successfully made crime the privileged turf of sociology. ${ }^{21}$ Criminology's higher level of abstraction also led sociologists to reflect on criminology's appropriate subject matter, beyond the narrowly legal definition of crime: Merton studied deviance; University of Pennsylvania's rising criminologist, Thorsten Sellin, considered the determination and violations of "conduct norms"; and Sutherland's analysis of "white collar" criminality questioned social scientists' exclusive focus on reported street crime and delinquency. ${ }^{22}$ With Merton gaining increasing stature within sociology, and Sutherland building a hub of American criminology at the University of Indiana (training future influential scholars such as Albert Cohen, Donald Cressey, and Lloyd Ohlin), their distinctive contributions had laid the foundations for the field's postwar mainstream.

\subsection{Delinquent Subcultures}

In the postwar period, social scientists gradually refined Merton and Sutherland's approaches with the aim to improve criminology's scientific status. Eventually, a dominant view emerged from research on the cultural dimensions of juvenile delinquency, which appeared to social scientists as well as private philanthropic foundations as a promising framework to integrate cross-disciplinary research on the links between relative deprivation and crime.

This consensus approach only emerged during the second half of the 1950s, though. Postwar debates in criminology, mostly led by sociologists, were primarily concerned with questions of method, a reflection of the preceding decade's advances. ${ }^{23}$ Sutherland's devastating critique of multifactor analysis had notably pressured those criminal "actuaries" interested in predictive studies to question their empirical methods. Consequently, calls for methodological refinementfewer variables, for example, or attention to statistical significanceovershadowed the older debates over the primacy of "personal" or "situational" factors in criminal or delinquent behavior. ${ }^{24}$ Sutherland's work on white-collar crime also stirred intense debate over
${ }^{20}$ Merton, "Social Structure and Anomie," 673, 672 .

${ }^{21}$ On Sutherland's opposition to the Gluecks and scientific positivism, see Laub and Sampson, "SutherlandGlueck Debate."

${ }^{22}$ Sutherland, "White-Collar Criminality."

\footnotetext{
${ }^{23}$ Mannheim, "American Criminology," 293. Advanced studies and research on criminology were conducted primarily within sociology departments, with the notable exception of Harvard and Berkeley. At Berkeley, August Vollmer had created the Bureau of Criminology within Berkeley's political science department in 1939. Yet, the training was mostly oriented toward the needs of policemen. A professional
} 
the field's proper subject matter, as he recommended investigation of a wider range of criminals, including white collars, and of crimes, than those defined within the narrow confines of the "traditional criminal code." 25 In keeping with Burgess, the debates pitted those who supported a legal definition of crime as law-breaking against the norm-violating definitions advanced by Sutherland and Merton. ${ }^{26}$ And, indeed, white-collar crime successfully developed into its own subfield in the late 1940s, with contributions from many prominent sociologists. Yet its integration within criminology remained intensely debated, with most criminologists agreeing with Donald Newman, that white-collar law-breaking was "a legitimate area of criminological research, although ... customarily set apart as a special type or 'behavior system' of crime." 27

These debates reveal that by the mid-1950s, criminology was still struggling to obtain the legitimacy won by sociology's postwar mainstream, with its joint embrace of survey analysis and structuralfunctionalism "symbolized by the pairing of [Samuel] Stouffer and [Talcott] Parsons at Harvard and [Paul] Lazarsfeld and Merton at Columbia." ${ }^{28}$ Merton was not publishing extensively on delinquency at the time and many details of Sutherland's differential association theory, easily equated with a Chicago tradition that was losing its shine, had scarcely been "subjected to the test of empirical research." 29 In contrast to the wider sociology discipline, many remained dissatisfied with criminology's lack of a "systematic theory" underpinning most of its empirical findings and predictive techniques. $3^{30}$

During the second half of the 1950s, refinements of the two leading frameworks-differential association and Merton's anomie theory - were intended to raise criminology's scientific status. Differential association was revised with a view to answering critics (e.g., the Gluecks) who argued that the theory poorly explained why some individuals became delinquents while their neighbors did not. ${ }^{31}$ Using social psychological concepts drawn from symbolic interactionism and role theory, some of its advocates insisted that individuals behaved in accordance with the way they expect to be perceived by others. ${ }^{32}$ Meanwhile, they sought to operationalize Sutherland's theory and test it empirically. ${ }^{33}$ Following Gresham Sykes and David Matza, criminologists developed a social psychological theory whereby delinquents shared most of the mainstream law-abiding values, but escaped self-blame by rationalizing their criminal acts with "techniques of neutralization" such as denial of the victim or condemnation of the condemners. 34 These refinements of differential association theory, however, did not spread beyond social psychology. Not only were cross-disciplinary exchanges scarce, but proponents of association, the American Society of Criminology, was created in 1941 with most of its members only remotely related to sociology. The first sociologist to serve as the president of the society was Walter Reckless in 1964. See Morris, "American Society of Criminology." 24 Schuessler, "Parole Prediction," 428.

${ }^{25}$ Newman, "White-Collar Crime," 737.

${ }^{26}$ For an overview of these debates, see Tappan, "Who Is the Criminal?" and Aubert, "White-Collar Crime and Social Structure."

${ }^{27}$ Newman, "White-Collar Crime," 735-36.

${ }^{28}$ Abbott and Sparrow, "Hot War, Cold War," 285

${ }^{29}$ Cressey, "Application and Verification," 43 and Abbot and Sparrow, "Hot War, Cold War," 296.

$3^{30}$ The lukewarm reception of the Gluecks' 1950 longitudinal study among sociologists illustrates these criticisms, which applied to most research on prediction in the 1950 s. See, for instance, Reiss, "Unraveling Juvenile Delinquency."

${ }^{31}$ Glaser, "Sociological Approach to Crime and Corrections."

${ }^{32}$ Matsueda, "Current State of Differential Association Theory."

${ }^{33}$ For example, Short, "Differential Association and Delinquency."

${ }^{34}$ Sykes and Matza, "Techniques of Neutralization." 
differential association also engaged in boundary work, feeding the sense among a number of social scientists that Sutherland's framework stood as an instance of sociological imperialism. ${ }^{35}$

Theories of delinquent subcultures formed another important strand of thought, one that merged differential association with Merton's functionalism. Starting with Albert Cohen's 1955 Delinquent Boys and followed by the works of, among others, Harvard anthropologist Walter Miller, Richard Cloward (a student of Merton's), and Lloyd Ohlin (a student of Sutherland's), this approach argued that delinquent subcultures were a collective response to the difficulties that individuals faced. Following Cohen, social scientists built typologies of subcultures and theoretical explanations for their formation, contributing to what arguably became the most influential strand in criminology until the second half of the 1960s. There were disagreements about whether the values of these subcultures were different from those of the poor and working class, or whether they emerged within specific family contexts (e.g., single-mother households), but, by the early 1960s, Cloward and Ohlin's Delinquency and Opportunity laid out what was arguably the most influential view. They argued that most delinquents strove to attain the economic status of the middle class, in the face of no real legitimate means to do so. In what was labeled the "opportunity theory," differences in access to various illegitimate means to achieve economic success explained the different forms of delinquency.

Criminology's fusion of differential association and Mertonian functionalism during the second half of the 1950 oxisted alongside a number of projects aimed at combining psychological, socialpsychological, and psychoanalytic insights to form a comprehensive and integrated approach. One index of this new interest was a 1955 conference organized by the Division of the Juvenile Delinquency of the Children's Bureau, which brought Merton and psychoanalyst Erik Erikson together. Another marker was a 1958 special issue on juvenile delinquency in the Journal of Social Issues, published by the American Psychological Association, which gathered Cohen and Miller, together with psychologists and social psychologists such as Albert Bandura, Richard Walters, and William and Joan McCord. With the prospect of a "synthesizing approach to American social problems," efforts were undertaken that nonetheless took note of Merton and Erikson's words of caution about the extent to which the sociologists' and psychologists' differences in perspective could be reconciled. ${ }^{36}$ Most followed Merton's views that a division of labor between sociologists and psychologists should prevail, with the former specializing in subculture formation and the latter locating delinquency either in pathological family dynamics or the process of
${ }^{35}$ Glaser, "Sociological Approach to Crime and Corrections," 686. A compelling illustration of boundary work is provided in Cressey, "Differential Association Theory and Compulsive Crimes," which rejects psychiatric explanations even in the case of compulsive crime. On the links between differential association and psychiatry, see also Hartung, "Critique of the Sociological Approach to Crime and Correction," 733-34. ${ }^{36}$ McCord, "Introduction," 3 and
Merton, "Concluding Comments and
an Example," 79. 
ego formation. 37 Although not the robust form of interdisciplinarity that some wished for, the new settlement was a step beyond the polarized debate that prevailed through to the early 1950s, which had set environmental explanations against personal factors. Because "no single field can offer a complete answer," most agreed that psychological, social-psychological, and sociological insights complemented, rather than supplanted, each other. ${ }^{38}$

By the early 1960s, social scientists reached a rough agreement about the causes of delinquency. As illustrated by subculture studies, sociologists shifted away from the interwar concern about the destabilizing effects of immigration and urbanization. Social scientists were now emphasizing the link between delinquency and the values and socioeconomic problems of lower-income communities. Although delinquency and gang crime were increasingly associated with racial minorities, social scientists maintained the prewar stance that crime was predominantly related to the social environment, not race per se: The dominant view was that higher rates of delinquency among African-Americans and in segregated neighborhoods were the product of poverty, cultural deprivation, and discrimination. 39

Interestingly, this emerging mainstream had arisen from studies of juvenile delinquents. To some extent, delinquency was a topic that allowed the social scientist to escape the definitional conundrum raised by the white-collar debates, because of its rather loose legal definition; delinquent behavior ranged from truancy, misdemeanors, and simple antisocial behavior, to more severe property offenses, violent acts, and sexual offenses. Scientists could, to some extent, cherry-pick their favored definition of crime, making delinquency a rallying point for different methodological viewpoints..$^{40}$ But studying the causes of delinquency also provided answers to a growing public concern that peaked during the second half of the $1950 \mathrm{Os} .{ }^{41}$ Delinquency rates were on the rise, and-while criminal statistics might not have been reliable-newspaper articles painted an alarming picture of youth criminality, which resonated with fears of communism and social disintegration. Meanwhile, the Senate began an almost decade-long series of hearings on the topic, and a number of local antidelinquency committees and organizations sprouted at the time. $4^{2}$

Since the late 1940s, philanthropic foundations had played no small role in supporting various antidelinquency programs, including social scientific studies. ${ }^{43}$ But the most influential program emerged from the Ford Foundation's attempts to fight relative deprivation, in particular by improving schooling, from the mid-1950s on. In this endeavor, officials of the foundation found in Cloward and Ohlin's work the theoretical underpinnings they needed. Ford funded their research at Columbia School of Social Work and developed the Mo-
${ }^{37}$ Merton, "Concluding Comments and an Example," 79. For psychological analyses, see McCord and McCord, "Effects of Parental Role Model on Criminality" and Erikson, "Ego Identity and the Psychosocial Moratorium."

${ }^{38}$ McCord, "Introduction," 3.

${ }^{39}$ Flamm, Law and Order, 17

${ }^{40}$ See Tappan, "Who Is the Criminal?" 99. The Gluecks, for instance, narrowed down the types of offenses in their definition of delinquency. See Glueck and Glueck, Unraveling Juvenile Delinquency, 13.

${ }^{41}$ For a thorough historical account of the problems of juvenile delinquency in postwar America, see Gilbert, Cycle of Outrage.

${ }^{42}$ Gilbert, Cycle of Outrage, 76, 63-64.

\footnotetext{
${ }^{43}$ For instance, Ohlin's, Miller's, and the Gluecks' research was funded by, respectively, the Russell Sage Foundation, the National Institutes of Health, and the Ford Foundation. By 1957, Ford had made juvenile delinquency an important aspect of its Youth Development program. A radical study of Russell
} 
bilization for Youth community action program (CAP), initiated by the board of directors of the Henry Street Settlement House in New York City to fight rising delinquency in the area, and cosponsored with the National Institute of Mental Health. The philosophy behind the project was similar to another significant Ford-sponsored urban renewal program, "Gray Areas," which emphasized the need to integrate people within mainstream community and its values. 44 The program promoted employment and educational support for young people, but also called for deeper reforms to broaden access to legitimate opportunities by improving job prospects and schooling. These demonstration programs sought to revise urban policies by combining the foundation's monies with the financial and institutional contributions of cities and the federal government. 45 In early 1961, Ford's programs inspired the creation of the President's Committee on Juvenile Delinquency and Youth Crime. Ohlin served as the liaison with the Department of Health, Education, and Welfare (HEW), which, after the Juvenile Delinquency and Youth Offenses Control Act of 1961, distributed \$30 million over three years to support pilot projects in crime control in the form of local community action-empowering programs.

In addition to support for these early attacks on poverty, HEW's funds sponsored a number of multidisciplinary research projects. One of them was held under the auspices of the social sciences division at the University of Chicago. Its head, the sociologist Morris Janowitz, sought to study "community organization" "as the basis of a preventive attack on juvenile delinquency." Reminiscent of Ford's goal to revamp urban policies, the project sought to integrate new social scientific knowledge with the practices of social workers and school teachers, and to improve the coordination of government, social welfare agencies, and local communities. ${ }^{46}$ What makes the Chicago project particularly interesting was Janowitz's hiring of the economist Belton Fleisher to estimate the empirical relationship between employment and delinquency. Recommended by the Chicago labor economist H. Gregg Lewis, Fleisher was arguably one of the first postwar economists to work on crime and delinquency. 47 Janowitz had hired Fleisher because studies by sociologists had "not been adequate in scope to deal with the complexity of the problem," as their research lacked an adequate policy orientation..$^{8}$ Eventually, in spite of Janowitz's plea to integrate the analysis of economic conditions within a framework emphasizing subcultures, the rigor and immediate policy implications of Fleisher's analysis impressed HEW officials. 49 This hinted at an interesting development that would create many tensions during Johnson's second mandate, namely, his conflation of the wars on crime and poverty.
Sage's funding activity found that Ohlin was, at the time, the largest recipient of Russell Sage's money (about a million dollars in cumulated grants in the 1950s and 1960s). Schulman, Brown, and Kahn, "Report on the Russell Sage Foundation."

${ }^{44}$ See Marris and Rein, Dilemmas of Social Reform and O'Connor, "Ford Foundation and Philanthropic Activism."

${ }^{45}$ See O'Connor, "Ford Foundation and Philanthropic Activism."

\footnotetext{
${ }^{46}$ Janowitz, "Proposal for Curriculum Development in Juvenile Delinquency and Crime Control," n.d., box 27, folder 3, Morris Janowitz Collection, Special Collections Research Center, University of Chicago Library.

${ }^{47}$ Lewis was a key player in the neoclassical turn of labor economics. He supervised many innovative PhD dissertations at Chicago, among which was Becker's 1955, The Economics of Racial Discrimination.

${ }^{48}$ Fleisher, Economics of Delinquency, 7 and Janowitz, "Final Progress Report," n.d., box 29, folder 2, Morris Janowitz Collection, Special Collections Research Center, University of Chicago Library.

49 Jack Otis to Morris Janowitz, August 6 , 1963, box 28, folder 14, Morris Janowitz Collection, Special Collections Research Center, University of Chicago Library.
} 


\subsection{The Politicization of Street Crime and Law and Order in the $1960 \mathrm{~s}$}

Paradoxically, the consensus idea that crime and delinquency were symptoms of broader social issues was sharply challenged during the 1960s, as street crime and civil unrest rose to the forefront of public debate. One result of the changed political climate was to call into question what was labeled the "rehabilitative ideal." 50

The increasing involvement of the federal government in matters of crime under Kennedy - a sea change in the history of US politicsplayed an important role in these developments, if only because its new prominence made the federal government more accountable for public safety. ${ }^{11}$ After Kennedy's small-scale attacks on delinquency, Johnson launched a full-fledged War on Poverty-an ambitious series of social welfare policies grounded on the belief that crime and delinquency were intertwined with other poverty-related problems such as discrimination and segregation of minorities, urban problems, and inequalities in access to many legitimate opportunities (see Chapter 4: Poverty). In line with the prevailing consensus, the Community Action Program (CAP), modeled after Ford's Mobilization for Youth, distributed funds on a decentralized basis to empower local communities. Yet it would only take Johnson a few months to make street crime a social (and federal) problem on its own, when he reframed the War on Poverty as a War on Crime..$^{2}$ In 1965, the Law Enforcement Assistance Act complemented the CAP with a small-scale crime control program that supported experimental law enforcement methods. 53 The surge in reported crime, together with the wave of race riots beginning in Harlem in 1964 and culminating in the "long summer" of 1967, convinced Johnson to consider the problem of street crime itself.54 Student protests would only add to this climate of unrest. With Republicans conflating street crime and civil disorders in a political rhetoric focused on "law and order" (see later), crime quickly became an especially charged issue in political discourse and public opinion. 55 Johnson would become the first US president to regularly submit "to Congress messages or speeches specifically on crime." 56

Indeed, Johnson established two important crime-related commissions, both of which gathered leading social scientists to reflect on causes and furnish policy recommendations: the first on crime, in 1965, chaired by the Attorney General Nicholas Katzenbach, and the second on civil disorders, in 1967, chaired by Illinois Governor Otto Kerner. The two commission reports supported Johnson's liberal creed that policy should target the socioeconomic root causes of crime and unrest. Likewise, they promoted community empower-

$5^{2}$ See, for instance, Flamm, Law and Order and Weaver, "Frontlash."

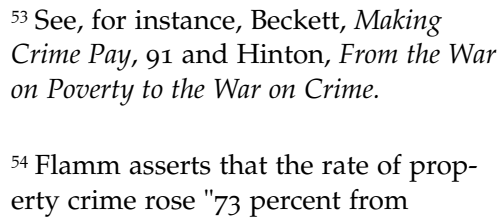

${ }^{55}$ Flamm, Law and Order, 2. See also Beckett, Making Crime Pay. Republicans' focus on law and order began during Barry Goldwater's presidential campaign against Johnson in 1964. ${ }^{56}$ Marion, History of Federal Crime Control Initiatives, 38 . 
ment, community integration of young people (in particular through the creation of "Youth Service Bureaus"), and the development of community relations programs within police departments. 57 Finally, they recommended increased spending on welfare programs directed at schooling, housing, training, and employment. Although economic analysis was conspicuously absent from both reports, most recommendations were compatible with the Council of Economic Advisers' endorsement of the War on Poverty at a time when the economics profession and various international institutions (such as the OECD) grew increasingly interested in the economics of education and human capital ideas (see Chapter 3: Education)..$^{8}$

The commission reports identified the typical criminal or rioter as coming from a dysfunctional family background, and they also supported welfare policies that would keep families together. In the second half of the 1960s, however, linking family disorganization to poverty and crime inescapably raised the issue of race (see Chapter 6: The Black Ghetto). Daniel Patrick Moynihan's controversial 1965 The Negro Family argued that a "tangle of pathology" within AfricanAmerican families, highly dependent on welfare and lacking father figures, had worsened socioeconomic disparities and generated delinquency. Like Moynihan's, the Kerner report argued that innercity segregation had fostered family and social disorganization, with poverty and unemployment, notably, preventing black males from their socially designated roles as fathers and breadwinners. 59 Rioting was "the behavioral response of men who were attempting to assert some form of power and control," according to some of the Kerner Commission experts. Reflecting the postwar consensus on prejudice marked by the characteristic themes of "social pathology, wounded masculinity, matriarchal families, and problematic self-esteem," these views would remain highly influential in both public policy circles and the social scientific literature until at least the late 1980s (see Chapter 5: Discrimination). ${ }^{60}$

The racial aspects of crime and unrest moved to center stage during Johnson's second term. Riots broke out in segregated neighborhoods, and reported crime figures showed that African-Americans were overrepresented as offenders, notably in violent crimes. ${ }^{61}$ Yet public opinion polls at the time showed increasing polarization along racial lines regarding the causes of crime and civil disorders. ${ }^{62}$ For many African-Americans, past and present racism, as well as police brutality, were major causes of unrest. Minority leaders and radicals presented social unrest as political upheaval. ${ }^{63}$ Influenced by the Black Panther Party and other minority movements, many activists rejected the idea-epitomized by the Moynihan report-that black innercity family life was a pathological shadow of white middle-class
57 These conclusions were not sociologists' only. Psychologists were also supporting these views, on the grounds that welfare policies were not a monetary or socioeconomic remedy to poor conditions, but a way to bolster self-esteem. See Herman, Romance of American Psychology, 223-25.

${ }^{58}$ See Teixeira, "Portrait of the Economics of Education."

${ }^{59}$ See Herman, Romance of American Psychology, chap. 8, for a thorough description of psychologists' work for the Kerner Commission.

${ }^{60}$ Herman, Romance of American Psychology, 222, 220, 201. See Hinton, From the War on Poverty to the War on Crime, for an analysis of the influence of these views.

${ }^{61}$ President's Commission on Law Enforcement and Administration of Justice, Challenge of Crime in a Free Society, 44 .

${ }^{62}$ Flamm, Law and Order, 83-84.

${ }^{63}$ See Flamm, Law and Order and Hinton, From the War on Poverty to the War on Crime, for a depiction of how these events were qualified as upheaval or riots. 
culture. Racial progress "could no longer automatically be equated with 'integration.' "'64 While many liberal social scientists - including Moynihan and those on the Kerner Commission-also blamed racism and discrimination, their integrationist posture was increasingly rejected by activists and protesters, leading a number of social scientists and policy officials to question community empowerment policies as potential contributors to unrest. ${ }^{6}$

These developments made structural-functionalism look "ill equipped" to address deep-seated conflict between groups. ${ }^{66} \mathrm{In}$ this changing social and intellectual landscape, criminologists were highly supportive of a number of approaches that studied the formation and consequences of "status assignment" by a group on another. Howard Becker's 1963 Outsiders stood as a landmark statement of the emerging field of "labeling" theories that, grounded in symbolic interactionism, studied how individuals' self-image and behavior are affected by the very act of labeling certain acts as deviant. Taking the problem from a slightly different angle, conflict theory-which reemerged after a 1966 article by sociologist Austin Turk-focused on the role that culture and group conflicts played in the production of legal and informal definitions of what counts as a deviant or criminal act. ${ }^{6}$ Because status ascription was imposed by the dominant, Turk's hypothesis that disadvantaged populations would be far more likely to be found delinquent paved the way for the subsequent emergence of radical criminology (see later).

During the second half of the 1960s, many whites took crime figures at face value and increasingly feared the surge in unrest and street crime-race-tinged anxiety that Republican political campaigns at the state and federal level increasingly fanned. In the wake of Barry Goldwater's 1964 presidential campaign, Republicans successfully seized "law and order" as a rallying cry to capture white working-class and middle-class discontent, conservative voters, and those who had opposed desegregation in the South a decade earlier. Illustrated by Ronald Reagan's successful 1966 gubernatorial campaign in California, as well as Richard Nixon's 1968 presidential campaign, conservative discourse demonized civil rights activism and linked civil disorder with street and violent crimes, implicitly targeting African-Americans. ${ }^{68}$ By setting aside discrimination, racism, and poverty as root causes, to focus instead on individual choice, morality, and family disintegration, many conservatives made the Great Society state itself responsible for welfare dependency, frustration, and violence among low-income and minority communities. ${ }^{69}$ Though most social scientists shied away from describing race as a determinant of crime, Republicans successfully appealed to sectors of the US electorate by drawing selectively on Moynihan's report or
${ }^{64}$ Jackson, Social Scientists for Social Justice, 3 .

${ }^{65}$ See, for instance, Fogelson, "Review Symposium" and Moynihan, Maximum Feasible Misunderstanding. Moynihan wrote that "empowerment" was promoted to the point that communities believed they could bypass or override "the city, the state, the world."

${ }^{66}$ Winant, "Dark Side of the Force," 565.

${ }^{67}$ Turk, "Conflict and Criminality."

${ }^{68}$ See Weaver, "Frontlash."

${ }^{69}$ Beckett, Making Crime Pay, 34. 
Marvin Wolfgang and Franco Ferracuti's 1967 analysis of AfricanAmericans' violence-prone subculture..$^{0}$

These attacks on liberal policies were strengthened by pointed criticisms of empirical research that, according to critics, failed to support the consensus tenets of mainstream criminology. The Harvard political scientist James Q. Wilson, among others, attacked the Crime Commission's recommendations precisely because the dearth of systematic evidence could not support "its generalizations and recommendations." ${ }^{71}$ Wilson's remarks hinted at the stream of countervailing evidence that questioned the conclusion, supported by the subculture approach, that delinquency was concentrated in urban low-income communities..$^{2}$ Research, moreover, that had attempted to operationalize Sutherland's differential association theory had not held up under systematic testing. Even prominent sociologist Donald Cressey conceded the empirical limits of differential association in 1960, an admission bolstered by the attacks of Travis Hirschi and Hannan Selvin, among others, on the principle of single causation. At a time when theoretical innovations appeared scant, many found that the bulk of theoretical analysis in criminology had never really met the standards of proper empirical analysis. 73 For these reasons, scholars such as Moynihan were skeptical of community empowerment policies, and warned against the dangers that a group of social scientists, supported by a few foundations' impressive pocketbooks, would impose their values on society, bypassing the sovereignty of citizens.74 Moreover, a number of comments pointing to the dearth of social scientific knowledge on law enforcement, its deterrent effect, and on the functioning of the criminal justice system, nurtured conservatives' insistence on shifting the emphasis away from offenders' rehabilitation toward public safety, deterrence, and punitive measures. 75 Because they were associated with rehabilitation and socioeconomic explanations of crime, sociologists were often portrayed as soft-hearted and ideologically driven scholars. ${ }^{6}$ By the end of Johnson's term, increasing doubts were cast on the possibility of solving the crime problem through welfare policies alone.

In the meantime, new ways of thinking about crime emerged in the aftermath of attempts by officials in Washington, who had been skeptical of the CAP since its beginning, to restore a more centralized approach to policymaking. Around the same time, the government extended the Department of Defense's Program Planning and Budgeting System (PPBS) to all federal agencies in 1965, hoping that cost-benefit and systems analyses would bring value-free criteria into public decision-making. ${ }^{77}$ This strong concern for cost-effectiveness provided a fertile ground for the development of alternative approaches to crime. Because "rational" policymaking depended heav-
${ }^{70}$ Wolfgang and Ferracuti, Subculture of Violence. By 1987, the book was still mentioned as a landmark analysis of violent subcultures. See Sampson, "Urban Black Violence."
${ }^{73}$ Cressey, "Epidemiology and Individual Conduct"; Hirschi and Selvin, "False Criteria of Causality"; Hirschi and Selvin, Delinquency Research; and Gibbs and Erickson, "Major Developments in the Sociological Study."

${ }^{74}$ See Moynihan, Maximum Feasible Misunderstanding.
77 See, for instance, Jardini, Thinking through the Cold War, 310 and Amadae, Rationalizing Capitalist Democracy, 68.

\begin{abstract}
${ }^{75}$ See Wilson, "Reader's Guide to the Crime Commission's Report," 2.

${ }^{76}$ James Kilpatrick's comment "that the [Crime] Commission's staff talked with too many sociologists, and not with nearly enough cops" provides a typical illustration. Quoted in Flamm, Law and Order, 56.
\end{abstract}


ily on the quality of empirical data, the Johnson administration gathered forty-one social scientists to produce a complementary "social report" that would account for social progress in the country. $7^{8}$ The endeavor was one instance of a broader movement led by social scientists determined to help transform the policymaking process by constructing "social indicators" that would accurately inform responses to social ills.79 Leading HEW's initiative, the sociologist Daniel Bell and economist Mancur Olson hoped to construct indicators with similar aggregative and interpretative characteristics as those already established for the economy. In the case of crime, Bell and Olson explored ways to overcome the limitations of the FBI report by weighting offenses by their relative seriousness (an approach initially developed by Marvin Wolfgang), as well as by computing the net monetary loss due to crime, including foregone earnings. ${ }^{80}$ Many social scientists warned against such "economic philistinism," some doubting the very possibility of building social indicators for policy purposes. ${ }^{81}$ Yet, from the late 1960s, systems analysis and economic conceptualization emerged as promising frameworks for integrating social scientific research into policymaking, paving the way for the study of deterrence and law enforcement. ${ }^{82}$

By 1968, crime had emerged as a standalone social problem, distinct from poverty, and a decisive one for the presidential election's outcome. Even before the end of Johnson's presidency, liberals' defeat was illustrated by the passing of the 1968 Omnibus Crime Control and Safe Streets Act. Increasingly skeptical of philanthropic foundations' support of political activism-in particular of local empowerment initiatives taking the form of registration campaigns-Congress also passed a law in 1969 that prohibited foundations from using their funds for political lobbying and elections. At the beginning of Nixon's term, then, the intellectual and political tide regarding the causes, prevention, and control of crime and delinquency had turned.

\subsection{The Emergence of "Crime Control"}

The 1968 Omnibus Crime Control and Safe Streets Act marked a significant shift toward crime control, in both policymaking and criminological research. In the wake of the 1967 Crime Commission, the Act relied on the concept of a "criminal justice" system to centralize and rationalize activities related to the control of street crime and civil unrest. ${ }^{83}$ The Act led to the creation of the Law Enforcement Assistance Administration (LEAA), a federal agency providing financial support to the states through block grants, under the condition that "statewide comprehensive law enforcement plans" were established. ${ }^{84}$ Consequently, significant support went to police op-
${ }^{78}$ US Department of Health, Education, and Welfare, Toward a Social Report. See also Fleury, "Drawing New Lines."

${ }^{79}$ Springer, "Social Indicators, Reports, and Accounts," 2.

\footnotetext{
${ }^{80}$ Bell, "Idea of a Social Report" and US Department of Health, Education, and Welfare, Toward a Social Report.

${ }^{81}$ Gross and Springer, "New Goals for Social Information," 218 and Reiss, "Putting Sociology into Policy."

${ }^{82}$ Savitz welcomed systems analysis as "the wave of the future." Savitz, "Review of The Challenge of Crime in a Free Society," 301.
}

${ }^{83}$ Orleans, "Criminal Justice, the Sociology of."

${ }^{84}$ Harman, "Bloc Grant," 142. 
erations and, to a lesser extent, social scientific research aimed at improving law enforcement and efficiency of correctional procedures. LEAA's influence on social scientific research grew stronger in time, as its grants became increasingly tied to "agency-defined research projects." ${ }^{85}$ Overall, the annual stream of LEAA funds kept rising throughout the 1970s, totaling $\$ 10$ billion by $1981 .{ }^{86}$ In the meantime, these grants progressively replaced other sources of federal money that once came from agencies that addressed the "social conditions of crime-such as urban development, housing, and health." 87

With the aim to upgrade educational requirements within enforcement agencies, the LEAA also fostered the massive development of "criminal justice" departments during the 1970s (they had more than tripled by 1976), through, for instance, the "consortium grants" given in 1973 to seven universities to develop specific doctoral degree programs. ${ }^{88}$ With a strong vocational aspect, these cross-disciplinary curricula gathered law enforcement professionals, legal scholars, economists, social psychologists, sociologists, psychologists, operations researchers, statisticians, and sometimes chemists and computer scientists, to study the organized response to crime by the various subsets of the criminal justice system, in particular correctional institutions, law courts, and the police. ${ }^{89}$ It is thus fair to say that although sociology remained the leading discipline within these departments in the 1970s, its leadership weakened. As criminology progressively moved away from sociology departments, the curricular prominence of sociological theory and methods receded too, in favor of more policy-oriented knowledge and techniques related to crime control, which emphasized statistics-the Federal Criminal Justice Statistics Program standing, by 1977, as "the fourth largest federal statistical program in the entire government" - and applications to the criminal justice and correctional systems. ${ }^{90}$ Interestingly, specialized outlets in criminology proved much more attractive for crime control and policy-related papers than traditional sociology outlets, the latter publishing, albeit on a modest scale, a higher share of "traditional" works about strain or learning theory. ${ }^{91}$

Following funding and institutional change in the 1970s, social scientific research progressively broke away from its main concern with criminal behavior and the social psychological forces driving it, to focus on crime control, the criminal justice system, and "the larger system of political economy."92 This opened the way for a new type of cross-disciplinary relationship that placed operations research $(\mathrm{OR})$ at the core of a nexus linking economists, statisticians, legal scholars, political scientists, and sociologists. Best illustrated by Alfred Blumstein's landmark works, OR gathered many disciplinespecific concepts and empirical results within a model of the criminal
${ }_{5}^{8}$ Savelsberg, Cleveland, and King, "Institutional Environments and Scholarly Work," 1278.

${ }^{86}$ Beckett, Making Crime Pay, 38, 91 and Hinton, From the War on Poverty to the War on Crime, 2.

${ }^{87}$ Short and Hughes, "Crime, Criminologists, and the Sociological Enterprise," 637.

\begin{abstract}
${ }^{88}$ Leijins, International Conference on Doctoral-Level Education, 5. The consortium universities were Arizona State, Eastern Kentucky, Michigan State, Northeastern, Portland State, the University of Nebraska at Omaha, and the University of Maryland, College Park.

${ }^{89}$ Leijins, International Conference on Doctoral-Level Education, 5.
\end{abstract}

${ }^{90}$ Leijins, International Conference on Doctoral-Level Education, 2. See also Bruns and O'Hearn, Criminal Justice Doctoral Education.

${ }^{91}$ Savelsberg, Cleveland, and King, "Institutional Environments and Scholarly Work."

${ }^{92}$ Laub, "Life Course of Criminology in the United States," 6. 
justice system designed as an "input/output process involving institutions and individuals using diverse resources to achieve social goals or output."93 Deeply related to program budgeting policies at the national and local level—after all, evaluation programs were being implemented by the RAND Corporation within a number of police departments at the time-this approach spurred a flourishing cross-disciplinary literature addressing problems related to the allocation of resources within law enforcement agencies and to the measurement of the cost of crime. ${ }^{94}$ These endeavors also incorporated the recent developments in statistics designed to overcome the limitations (and underestimation) of FBI crime figures, in particular the victimization surveys by sociologists. 95

The increased attention paid to the performance of the criminal justice system supported economists' managerial view that-because both crime and its prevention were costly-there existed an optimal balance of enforcement and crime in a given society. The point was forcefully stated in Gary Becker's widely influential article of $1968 .^{96}$ The two central notions on which it was built, rational choice and deterrence, were rapidly assimilated within the other social sciences as well. OR is an obvious example, as it was customarily conflated with economic analysis. But rational choice and cost-effectiveness made their way into political science through Wilson's work, in particular his massively influential Thinking about Crime, which welcomed OR and economics as means to "to test the efficacy of alternative crime control strategies." 97 In sociology, both Travis Hirschi's social control theory, which sought to analyze why individuals did not break the law, and Lawrence Cohen and Marcus Felson's late 1970s "routine activity" theory, which stressed the role that situational incentives play in the occurrence of crime, relied on some form of rational behavior. ${ }^{98}$ Moreover, sociologists' traditional skepticism toward deterrence started to wane with the works of Jack Gibbs and Charles Tittle, which contributed to the debate-largely dominated by economistson the effect of severity and probability of punishment on crime. ${ }^{99}$ One should note that economics' increasing influence on the social scientific discourse did not imply that noneconomists wholeheartedly embraced its assumptions. ${ }^{100}$ Overall, most of them remained aware of rational choice's limitation and-judging from the debates on the deterrent effect of capital punishment, reinvigorated by Isaac Ehrlich's econometric studies in the mid-1970s - noneconomists appeared more cautious than economic students of crime on the conclusiveness and applicability of research on deterrence. ${ }^{101}$

Even so, the emerging mainstream trend in criminology systematized what had become, since the late 1960s, a consensus view among policymakers and officials, namely, that welfare policies aim-
93 "The Cost of Crime and of Social Defense against Crime," 196.
${ }_{97}$ Wilson, Thinking about Crime, xxii.

${ }^{98}$ Cohen and Felson, "Social Change
and Crime Rate Trends."

${ }_{99}^{9}$ See, for instance, Tittle, "Punishment and Deterrence of Deviance" and Gibbs, Crime, Punishment, and Deterrence.

${ }^{100}$ The cross-disciplinary conference organized by the American Enterprise Institute in 1972 shows that the dialogue between economists and sociologists on matters of crime control remained difficult even when they shared common beliefs about deterrence. See Rottenberg, Economics of Crime and Punishment.

${ }^{101}$ See, for instance, the report of the Panel on Research on Deterrence and Incapacitative Effects, which, among other things, evaluated Ehrlich's results. Note that Ehrlich was a student of Becker's in the mid-196os. 
ing at the root causes of crime were ineffective at curbing crime. ${ }^{102}$ This appraisal was notably shared by a number of Nixon's advisers, notably Moynihan, Wilson, and political scientist Edward Banfield, and by a number of other social scientists later labeled "neoconservatives." To them, Johnson's welfare policies were biased misuses of social scientific research that only reflected the almost utopian values of a new class of experts. The critics wished to promote, instead, a more pragmatic use of social science, combined with a sharp reduction in the scope of government's intervention-ideas that they successfully publicized in Irving Kristol and Daniel Bell's The Public Interest, first published in 1965.

Yet the shift in scholarly and institutional focus to criminal justice and crime control was heavily criticized by many scholars within the academic community. ${ }^{103}$ Social scientists feared, first, that the vocational aspect of these curricula would lead to a "smothering of social science knowledge."104 A decade after their creation, such a tension was registered within LEAA-sponsored programs in criminal justice, between the "professional" and the "social scientific" aspects, or whether particular doctoral students should be awarded a $\mathrm{PhD}$ or a DCrim. ${ }^{105}$ But the criticisms extended to the policy-oriented research that Ehrlich's or Wilson's works exemplified too, revealing how debates over the scientific character of crime control-related research were enmeshed with policy and political considerations. To some, such as Cressey, "doing something about crime," especially when it was equated with a racially or class-biased pursuit of criminals, had nothing to do with the pursuit of truth. ${ }^{106}$ Opposing Wilson's comments about the uselessness of sociology, Cressey forcefully retorted that only empirical generalizations about the root causes of criminal behavior could ground a scientifically sound fight against crime.

Another strand of attack on criminology during the 1970s came from a radical "new criminology," grounded in a series of foundational critiques of sociological and psychological criminologies, and of Becker's economics of crime. ${ }^{107}$ A burgeoning subfield-thanks to the leading role of Berkeley's Department of Criminology and a new journal, Crime and Social Justice-radical criminology focused on the relationship between crime and political or institutional structures, where conflict over power stood as a central process behind lawmaking and status ascription. ${ }^{108}$ To radicals, the criminologist helped the state rationalize penal practices and law enforcement-reflected, in other words, the "values of the State," and helped reinforce the criminalization of working classes' or minorities' behavior by the power elite. ${ }^{109}$ Increasingly linked to Marxian thought and drawing together the insights of political economy, philosophy, the sociology of deviance, and political science, radicals sought to redefine the
${ }^{102}$ Hinton, From the War on Poverty to the War on Crime, 181-82.

${ }^{105}$ Bruns and $\mathrm{O}^{\prime}$ Hearn, Criminal Justice Doctoral Education.

${ }^{106}$ Cressey, "Criminological Theory, Social Science."

${ }^{107}$ On the first type of critique, see Taylor, Walton, and Young, New Criminology. For a critique of Becker's economics of crime, see Gordon, "Capitalism, Class, and Crime."

${ }^{108}$ Greenberg, Crime and Capitalism, 3.

${ }^{109}$ Platt, "The Prospects for Radical Criminology," 2. 
"true" crimes of capitalist societies, in particular alienation, racism, imperialism, exploitation, and political oppression of dissenters. Yet, after a promising start, the movement quickly lost momentum, as many scholars eventually rejected radicals' dogmatism. By the 1980s, the field had mostly "excommunicated radical criminology from the American scene."110

While radicals' ambitious program failed to convince social scientists, economists' endeavors to redefine criminal law within a framework inspired by the works of Ronald Coase, Harold Demsetz, Becker, and, perhaps most importantly, Richard Posner, proved quite successful. This view analyzed law as a tool for public policy aiming at maximizing society's wealth and limiting government's intervention, thanks notably to its deterrent effect. Although a number of legal scholars interested in the economic approach argued for a redistributive role for law, and questioned economists' focus on deterrence, the scholarship that addressed criminal law in particular was heavily indebted to Becker's early definition of crime as uncompensated harm and his focus on fines as optimal punishment. Research on the topic would eventually take off in the mid-1980s with Posner's reformulation of crime as "market bypassing," written, like most of his work, for an audience of legal scholars. ${ }^{111}$ Closely tied to the University of Chicago and neoliberal circles such as the Mont Pèlerin Society, the movement did not suffer the fate of radicals, and kept expanding in the $1980 \mathrm{os}$. One reason might be that, in contrast to the radicals, the economic analysis of legal rules was never orthogonal (but quite complementary) to the topical problems related to the rational management of crime through law enforcement and deterrence.

By the early 1980s, indeed, the cost-efficiency of the criminal justice system was becoming a pressing issue that concerned not only economists but also other social scientists and policymakers, as the first consequences of the "get tough on crime" policies, promoted ever since Nixon, were being felt. With the hope that deterrence would prevent future crime, anticrime policies during the 1970 s had promoted harsher punishments, the militarization of police forces, and the development of surveillance techniques. ${ }^{112}$ Policymakers' focus on street crime had made African-Americans the primary target of crime control policies, a trend worsened by the war on drugs initially declared under Nixon, but strongly revived under Reagan. By the time of Reagan's election, the movement of mass incarceration had dramatically changed the racial composition of prisons, while the cost of incarceration put huge strains on public finance. This pressing issue strengthened the development of predictive analysis in the 1980s, a subfield that had been rejuvenated by the 1972 longitudinal
${ }^{110}$ Koheler, "Development and Fracture of a Discipline," 536.

${ }^{111}$ Posner, "Economic Theory of Criminal Law." See also Posner, Economic Analysis of Law. For an overview of the debates between economists and legal scholars on the use of economic analysis to study law, see Hackney, Under Cover of Science and Marciano and Medema, "Disciplinary Collisions."

${ }^{112}$ See Hinton, From the War on Poverty to the War on Crime. 
study by Marvin Wolfgang, Robert Figlio, and Thorsten Sellin. ${ }^{113}$ Because its main result showed that a small fraction of delinquents contributed to most delinquency, Wolfgang's study recommended allocating crime control resources to targeted criminals, thus setting the stage for research on "career criminals" and selective incapacitation in the 1980s, with drugs becoming an important causal factor of crime in the social scientific and public discourses. ${ }^{114}$ Predictive analyses that could be used, for instance, to estimate the probabilities of parole violation, or to "distinguish the high-rate offenders from the more numerous ordinary offenders," would be at the heart of decision guidelines that were used on a voluntary basis by parole boards. ${ }^{115}$ Finally, the development of predictive research on sentencing in the 1980 os certainly benefited from the implementation, in a number of states and cities, of mandatory sentences, in particular for drug-related felonies, unlawful gun possession, or recidivism.

The focus on the prevention of future crime also helped encourage the revival of biological explanations. The British psychiatrist Hans Eysenck assumed a leading role in the revival, as he focused on the role of inherited traits of the cortical and autonomic nervous systems, to which difficulties in both learning and inhibiting antisocial behavior were related. ${ }^{116}$ Although his early works stretched back to the mid-1960s, Eysenck's work became increasingly influential in the 1970 and spurred a stream of studies that illustrated the change in predictive methods away from clinical to statistical prediction in the psychiatry of crime of the early 1980s. ${ }^{117}$ Moreover, the mid-1980s revival of studies emphasizing heredity while exploring the links between criminality and personality traits-IQ in particular-opened the way for the merging of political science and psychology, thanks to the collaboration between Wilson and the psychologist Richard Herrnstein. ${ }^{118}$ In 1994, The Bell Curve, coauthored by Herrnstein and conservative political scientist Charles Murray, framed the former's findings on IQ and crime within a broader picture of America's social (and racial) inequalities, with conclusions that left little room for social welfare policies. Although Eysenck and Herrnstein held different positions on rational choice and the potential for the rehabilitation of criminals, they both made biological explanations of criminal behavior highly influential again.

\subsection{Conclusion}

On the eve of the late-1990s historic drop in crime rates, Bill Clinton's 1994 Violent Crime Control and Law Enforcement Act, the largest federal crime control bill at the time, toughened punishment and expanded federal oversight, illustrating that the "tough on crime" ${ }^{113}$ Wolfgang, Figlio, and Sellin, Delin-
quency in a Birth Cohort.

${ }^{114}$ Hinton, From the War on Poverty to the War on Crime.

${ }^{115}$ Blumstein et al., Criminal Careers and "Career Criminals," vi. On guidelines, see Goldkamp, "Prediction in Criminal Justice Development."

${ }^{116}$ Hollin, Psychology and Crime, 55-58.

${ }^{117}$ Eysenck and Gudjonsson, The Causes and Cures of Criminality, ix.

${ }^{118}$ See Wilson and Herrnstein, Crime and Nature and Herrnstein and Murray, The Bell Curve. 
stance had crossed the political divide. Meanwhile, the links between research on crime control and policymaking kept tightening. Wilson and George Kelling's 1982 "broken windows" theory, which argued that police should systematically address misdemeanors in order to prevent the development of a seriously criminogenic environment, reached high levels of respectability, as its implementation through New York City's mid-199os "quality of life policing" seemed to offer strong empirical validation. ${ }^{119}$

Yet the dominance of crime control research programs should not conceal the increasing fragmentation of social scientific knowledge: Not only did this orientation not replace other research programs on crime but its most important theoretical developments remained discipline-specific. Although research was already splintered as early as the interwar period, when biological, psychological, and sociological explanations of crime coexisted, social scientists were less committed to building an integrated interdisciplinary approach after the 1980 , with criminal justice programs as a case in point.

Over time, the shifts in methodological mainstreams and leading cross-disciplinary relations were always related to the interaction between debates about the relevant criteria for proper scientific research, on the one hand, and public policy concerns for delinquency or crime control, on the other. A byproduct of the criminal justice turn in the 1970s, criminology's separation from sociology mirrored the dissociation of crime from poverty in the public and policy discourses. By the 1980s, sociology had lost its dominant position. Biological explanations resurfaced after years of rejection, and economics and political science established themselves as promising challengers. OR and psychological or psychiatric research on personal traits provided cross-disciplinary frameworks capable of integrating social scientific and biological knowledge into policy-relevant material.

One distinctive aspect of the changes that occurred in the late 1960s, and that divided scholars both within and outside criminology, concerned the relationship between research and public policy. ${ }^{120}$ From scholarship driven by social reform built on social scientific knowledge independent of government's oversight, a significant chunk of criminological research seemed to have become tethered to crime-control policy. While this dependence pressured a number of criminologists to constantly reevaluate their achievements through the prism of policy-relevance, the broad shift to criminal justice-to making the penal system "work" — proved alarming to the growing ranks of political scientists, historians, and criminologists who warned that crime, and its management, had become the foundation of a new, less democratic, and racially polarized American civil and political order. $^{121}$
${ }^{119}$ Harcourt, "Reflecting on the Subject."

${ }^{120}$ See Petersilia, "Policy Relevance and the Future of Criminology," 397.

${ }^{121}$ Simon, Governing through Crime, 6. 


\section{Bibliography}

Abbott, Andrew, and James Sparrow. "Hot War, Cold War: The Structures of Sociological Action, 1940-1955." In Sociology in America: A History, edited by Craig Calhoun, 281-313. Chicago: Chicago University Press, 2007.

Amadae, Sonja. Rationalizing Capitalist Democracy: The Cold War Origins of Rational Choice Liberalism. Chicago: University of Chicago Press, 2003.

Aubert, Vilhelm. "White-Collar Crime and Social Structure." American Journal of Sociology 58, no. 3 (1952): 263-71.

Becker, Gary S. "Crime and Punishment: An Economic Approach." Journal of Political Economy 76, no. 2 (1968): 169-217.

Becker, Howard S. Outsiders: Studies in the Sociology of Deviance. New York: Free Press, 1963.

Beckett, Katherine. Making Crime Pay: Law and Order in Contemporary American Politics. Oxford: Oxford University Press, 1997.

Bell, Daniel. "The Idea of a Social Report." The Public Interest 15 (Spring 1969): 72-105. Bell, Daniel. The End of Ideology. Cambridge: Harvard University Press, 2000.

Blumstein, Alfred, Jacqueline Cohen, and Daniel Nagin, eds. Deterrence and Incapacitation: Estimating the Effects of Criminal Sanctions on Crime Rates. Panel on Research on Deterrent and Incapacitative Effects. Washington, DC: National Academy of Sciences, 1978.

Blumstein, Alfred, Jacqueline Cohen, Jeffrey A. Roth, and Christy A. Visher, eds. Criminal Careers and "Career Criminals". Washington, DC: National Academy Press, 1986.

Bottoms, Albert M. "Operations Research and Computers in Law Enforcement: Some Cases Studies of American Police Experience." Computers \& Operations Research 1, no. 1 (1974): 149-65.

Bruns, Gilbert H., and Carolyn O'Hearn. Criminal Justice Doctoral Education: Issues and Perspectives. Washington, DC: National Criminal Justice Educational Consortium Reports 4, 1976.

Buchanan, James. "Student Revolts, Academic Liberalism, and Constitutional Attitudes." Social Research 35 (1968): 666-80.

Bulmer, Martin. The Chicago School of Sociology. Chicago: University of Chicago Press, 1984.

Burgess, Ernest. "The Study of the Delinquent as a Person." American Journal of Sociology 27, no. 6 (1923): 657-80.

Burgess, Ernest. "Is Prediction Feasible in Social Work? An Inquiry Based upon a Sociological Study of Parole Records." Social Forces 7, no. 4 (1929): 533-45.

Chapoulie, Jean-Michel. "Ernest W. Burgess et les débuts d'une approche sociologique de la délinquance aux Etats-Unis." Déviance 
et Société 27 (2003): 103-10.

Clinard, Marshall B. "Sociologists and American Criminology." Journal of Criminal Law and Criminology 41, no. 5 (1951): 549-77.

Cloward, Richard A, and Lloyd E. Ohlin. Delinquency and Opportunity: A Theory of Delinquent Gangs. Glencoe: Free Press, 1960.

Cohen, Albert K. Delinquent Boys: The Culture of the Gang. Glencoe: Free Press, 1955.

Cohen, Lawrence, and Marcus Felson. "Social Change and Crime Rate Trends." American Sociological Review 44, no. 4 (1979): 588608.

"The Cost of Crime and of Social Defense Against Crime: Summary of the Second International Symposium in Comparative Criminology." Acta Criminologica 4 (1971): 193-208.

Cressey, Donald. "Application and Verification of the Differential Association Theory." Journal of Criminal Law and Criminology 43, no. 1 (1952): 43-52.

Cressey, Donald. "The Differential Association Theory and Compulsive Crimes." Journal of Criminal Law, Criminology, and Police Science 45, no. I (1954): 29-40.

Cressey, Donald. "Epidemiology and Individual Conduct: A Case from Criminology." Pacific Sociological Review 3, no. 2 (1960): 4758.

Cressey, Donald. "Criminological Theory, Social Science and the Repression of Crime." Criminology 16, no. 2 (1978): 171-91.

Davie, Neil. "The Impact of Anthropological Criminology in Britain (1880-1918)." Histoire de la criminologie 4, l'Anthropologie criminelle en Europe, 2005.

Douglas, Jack. "Review of The Challenge of Crime in a Free Society: A Report by the President's Commission on Law Enforcement and Administration of Justice." American Sociological Review 32, no. 4 (1967): 664-66.

Erikson, Erik. "Ego Identity and the Psychosocial Moratorium." In New Perspectives for Research on Juvenile Delinquency, edited by Ellen Witmer and Ruth Kotinsky, 1-23. Washington, DC: US Department of Health, Education, and Welfare, 1956.

Eysenck, Hans, and Gisli Gudjonsson. The Causes and Cures of Criminality. New York: Springer, 1989.

Flamm, Michael. Law and Order: Street Crime, Civil Unrest and the Crisis of Liberalism. New York: Columbia University Press, 2005.

Fleisher, Belton M. The Economics of Delinquency. Chicago: Quadrangle Books, 1966.

Fleury, Jean-Baptiste. "Drawing New Lines: Economists and Other Social Scientists on Society in the 1960s." In The Unsocial Social Science? Economics and Neighboring Disciplines since 1945, edited 
by Roger E. Backhouse and Philippe Fontaine, 315-42. Durham: Duke University Press, 2010.

Fogelson, Robert. "Review Symposium." American Political Science Review 63, no. 4 (1969): 1269-75.

Gage, Beverly. "Counting Crime: J. Edgar Hoover, the Wickersham Commission, and the Problem of Criminal Statistics." Marquette Law Review 93, no. 4 (2013): 1109-18.

Garland, David. The Culture of Control: Crime and Social Order in Contemporary Society. Chicago: University of Chicago Press, 2001. Garofalo, Raffaele. La criminologie. Paris: Félix Alcan, 1888.

Gibbs, Jack P. Crime, Punishment, and Deterrence. New York: Elsevier, 1975.

Gibbs, Jack P., and Maynard Erickson. "Major Developments in the Sociological Study of Deviance." Annual Review of Sociology 1 (1975): 21-42.

Gilbert, James. A Cycle of Outrage: America's Reaction to the Juvenile Delinquent in the 1950s. Oxford: Oxford University Press, 1986.

Gitre, Edward. "Importing Freud: First-Wave Psychoanalysis, Interwar Social Sciences, and the Interdisciplinary Foundations of an American Social Theory." Journal of the History of the Behavioral Sciences 46, no. 3 (2010): 239-62.

Glaser, Daniel. "The Sociological Approach to Crime and Corrections." Law and Contemporary Problems 23, no. 4 (1958): 683-702.

Glueck, Sheldon, and Eleanor Glueck. One Thousand Juvenile Delinquents. Cambridge: Harvard University Press, 1934.

Glueck, Sheldon, and Eleanor Glueck. Unraveling Juvenile Delinquency. New York: The Commonwealth Fund, 1950.

Goldkamp, John S. "Prediction in Criminal Justice Policy Development." Crime and Justice 9 (1987): 103-50.

Gordon, David. "Capitalism, Class, and Crime in America." Crime and Delinquency 19, no. 2 (1973): 163-86.

Goring, Charles. The English Convict: A Statistical Study. London: H. M. Stationery Office, 1913.

Greenberg, David. Crime and Capitalism. Philadelphia: Temple University Press, 1993.

Grisso, Thomas. "Forensic Evaluation in Delinquency Cases." In Handbook of Psychology: Forensic Psychology, vol. 11, edited by Alan M. Goldstein, 315-34. Hoboken: John Wiley \& Sons, 2003.

Gross, Bertram, and Michael Springer. "New Goals for Social Information." Annals of the American Academy of Political and Social Science 388, no. 1 (1967): 208-18.

Hackney, James R. Under Cover of Science. Durham: Duke University Press, 2007.

Harcourt, Bernard E. "Reflecting on the Subject: A Critique of the 
Social Influence Conception of Deterrence, the Broken Windows Theory, and Order-Maintenance Policing New York Style." Michigan Law Review 97, no. 2 (1998): 291-389.

Harcourt, Bernard E. Against Prediction: Profiling, Policing and Punishing in an Actuarial Age. Chicago: University of Chicago Press, 2007.

Harman, Douglas. "The Bloc Grant: Readings from a First Experiment." Public Administration Review 30, no. 2 (1970): 141-53.

Hartung, Frank E. "A Critique of the Sociological Approach to Crime and Correction." Law and Contemporary Problems 23, no. 4 (1958): 703-34.

Healy, William. The Individual Delinquent. London: Little, Brown, 1915.

Herman, Ellen. The Romance of American Psychology: Political Culture in the Age of Experts. Berkeley: University of California Press, 1995.

Herrnstein, Richard J., and Charles Murray. The Bell Curve: Intelligence and Class Structure in American Life. New York: Free Press, 1994.

Hinton, Elizabeth. From the War on Poverty to the War on Crime: The Making of Mass Incarceration in America. Cambridge: Harvard University Press, 2016.

Hirschi, Travis, and Hanan Selvin. "False Criteria of Causality in Delinquency Research." Social Problems 13, no. 3 (1966): 254-68.

Hirschi, Travis, and Hanan Selvin. Delinquency Research: An Appraisal of Analytic Method. London: Transaction Publishers, 1967.

Hollin, Clive. Psychology and Crime: An Introduction to Criminal Psychology. London: Routledge, 1989.

Hollin, Clive. "Criminal Psychology." In Oxford Handbook of Criminology, edited by Mike McGuire, Rod Morgan, and Robert Reiner, 43-77. Oxford: Oxford University Press, 2012.

Jackson, John P., Jr. Social Scientists for Social Justice: Making the Case against Segregation. New York: New York University Press, 2001.

Morris Janowitz Collection. Special Collections Research Center, University of Chicago Library.

Jardini, David. Thinking through the Cold War: RAND, National Security and Domestic Policy, 1945-1975. Meadows Land: David Jardini.

Koheler, Johann. "Development and Fracture of a Discipline: Legacies of the School of Criminology at Berkeley." Criminology 53, no. 4 (2005): 513-44.

Laub, John H. "The Life Course of Criminology in the United States: The American Society of Criminology 2003 Presidential Address." Criminology 42, no. I (2004): 1-26.

Laub, John H., and Robert J. Sampson. "The Sutherland-Glueck Debate: On the Sociology of Criminological Knowledge." American Journal of Sociology 96, no. 6 (1991): 1402-40. 
Leijins, Peter P. International Conference on Doctoral-Level Education in Criminal Justice and Criminology. College Park: Institute of Criminal Justice and Criminology, University of Maryland, 1977.

Lindesmith, Alfred, and Yale Levin. "The Lombrosian Myth in Criminology." American Journal of Sociology 42, no. 5 (1937): 653-71.

Mannheim, Hermann. "American Criminology: Impressions of an European Criminologist." British Journal of Sociology 5, no. 4 (1954): 293-308.

Marciano, Alain, and Steven G. Medema. "Disciplinary Collisions: Blum, Kalven, and the Economic Analysis of Accident Law at Chicago in the 1960s." In Law and Economics as Interdisciplinary Practice, edited by Magdałena Malecka and Peter Cserne, 53-75. New York: Routledge, 2020.

Marion, Nancy E. A History of Federal Crime Control Initiatives, 19601993. Westport: Praeger Publishers, 1994.

Marris, Peter, and Martin Rein. Dilemmas of Social Reform: Poverty and Community Action in the United States. Chicago: Aldine, 1973.

Matsueda, Ross. "The Current State of Differential Association Theory." Crime and Delinquency 34 (1988): 277-306.

McCord, Joan, and William McCord. "The Effects of Parental Role Model on Criminality." Journal of Social Issues 14, no. 3 (1958): 66-75.

McCord, William. "Introduction." Journal of Social Issues 14, no. 3 (1958): 3-4.

Merton, Robert K. "Social Structure and Anomie." American Sociological Review 3, no. 5 (1938): 672-82.

Merton, Robert K. "Concluding Comments and an Example of Research." In New Perspectives for Research on Juvenile Delinquency, edited by Ellen Witmer and Ruth Kotinsky, 75-92. Washington, DC: US Department of Health, Education, and Welfare, 1956.

Michael, Jerome, and Mortimer, J. Adler. Crime, Law, and Social Science. New York: Harcourt, Brace \& Co, 1933.

Miller, Walter B. "Lower Class Culture as Generating a Milieu of Gang Delinquency." Journal of Social Issues 14, no. 3 (1958): 5-19.

Morris, Albert. "The American Society of Criminology: A History, 1941-1974." Criminology 13, no. 2 (1975): 123-67.

Moynihan, Daniel Patrick. The Negro Family: The Case for National Action. Washington, DC: US Government Printing Office, 1965.

Moynihan, Daniel Patrick. Maximum Feasible Misunderstanding. New York: Free Press, 1969.

Newman, Donald J. "White-Collar Crime." Law and Contemporary Problems 23, no. 4 (1958): 735-53.

O'Connor, Alice. "The Ford Foundation and Philanthropic Activism in the 1960s." In Philanthropic Foundations: New Scholarship, New 
Possibilities, edited by Ellen Condliffe Lagemann, 169-94. Bloomington: Indiana University Press.

Orleans, Myron. "Criminal Justice, Sociology of." In International Encyclopedia of the Social and Behavioral Sciences, edited by James D. Wright, 214-18. New York: Elsevier, 2015.

Petersilia, Joan. "Policy Relevance and the Future of Criminology." In Contemporary Masters in Criminology, edited by Joan McCord and John H. Laub, 389-408. New York: Plenum Press, 1995.

Platt, Tony. "Prospects for a Radical Criminology in the United States." Crime and Social Justice I (1974): 2-10.

Posner, Richard A. Economic Analysis of Law. Boston: Little, Brown, 1973.

Posner, Richard A. "An Economic Theory of the Criminal Law." Columbia Law Review 85, no. 6 (1985): 1193-1231.

President's Commission on Law Enforcement and Administration of Justice. The Challenge of Crime in a Free Society. Washington, DC: US Government Printing Office, 1967.

Reiss, Albert. "Unraveling Juvenile Delinquency. II. An Appraisal of the Research Methods." American Journal of Sociology 57, no. 2 (1951): 115-20.

Reiss, Albert. "Putting Sociology into Policy." Social Problems 17, no. 3 (1970): 289-94.

Rottenberg, Simon. The Economics of Crime and Punishment. Washington, DC: American Enterprise Institute, 1973.

Sampson, Robert J. "Urban Black Violence: The Effect of Male Joblessness and Family Disruption." American Journal of Sociology 93, no. 2 (1987): 348-83.

Sampson, Robert J., and John H. Laub. Crime in the Making. Cambridge: Harvard University Press, 1995.

Savelsberg, Joachim, Lara Cleveland, and Ryan King. "Institutional Environments and Scholarly Work: American Criminology, 19511993." Social Forces 82, no. 4 (2004): 1275-1302.

Savitz, Leonard. "Review of The Challenge of Crime in a Free Society." Social Force 46, no. 2 (1967): 300-1.

Schuessler, Karl F. "Parole Prediction: Its History and Status." The Journal of Criminal Law, Criminology, and Police Science 45, no. 4 (1954): 425-31.

Schulman, Jay, Carol Brown, and Roger Kahn. "Report on the Russell Sage Foundation." Critical Sociology 2, no. 4 (1972): 2-34.

Shaw, Clifford, and Henry McKay. "Social Factors in Juvenile Delinquency: A Study of the Community, the Family, and the Gang in Relation to Delinquent Behavior." In Report of the National Commission on Law Observance and Enforcement, Causes of Crime. Vol. 2. Washington, DC: US Government Printing Office, 1929. 
Short, James F. "Differential Association and Delinquency." Social Problems 4, no. 3 (1957): 233-39.

Short, James F., and Lorine A. Hughes. "Criminology, Criminologists, and the Sociological Enterprise." In Sociology in America: A History, edited by Craig Calhoun, 605-38. Chicago: University of Chicago Press, 2007.

Simon, Jonathan. Governing Through Crime. Oxford: Oxford University Press, 2007.

Skogan, Wesley G. "Review of Surveying Crime, by the National Research Council." The Journal of Criminal Law and Criminology 69, no. 1 (1978): 139-40.

Springer, Michael. "Social Indicators, Reports, and Accounts: Toward the Management of Society." Annals of the American Academy of Political and Social Science 388, no. I (1970): 1-13.

Steinmetz, George. "American Sociology before and after World War II: The (Temporary) Setting of a Disciplinary Field." In Sociology in America: A History, edited by Craig Calhoun, 314-66. Chicago: University of Chicago Press, 2007.

Sullivan, Richard F. "The Economics of Crime: Introduction to the Literature." Crime and Delinquency 19, no. 2 (1973): 138-49.

Sutherland, Edwin H. Principles of Criminology. New York: J. B. Lippincott Company, 1939.

Sutherland, Edwin H. "White-Collar Criminality." American Sociological Review 5, no. 1 (1940): 1-12.

Sykes, Gresham M., and David Matza. "Techniques of Neutralization." American Sociological Review 22, no. 6 (1957): 664-70.

Tappan, Paul. "Who Is the Criminal?" American Sociological Review 12, no. 1 (1947): 96-102.

Taylor, Ian, Paul Walton, and Jock Young, The New Criminology: For a Social Study of Deviance. London: Routledge \& Kegan Paul, 1973.

Teixeira, Pedro. "A Portrait of the Economics of Education, 19601997." In Toward a History of Applied Economics, edited by Roger E. Backhouse and Jeff Biddle, 257-88. Durham: Duke University Press, 2000.

Tittle, Charles. "Punishment and Deterrence of Deviance." In The Economics of Crime and Punishment, edited by Simon Rottenberg, 85-102. Washington, DC: American Enterprise Institute.

Turk, Austin T. "Conflict and Criminality." American Sociological Review 31, no. 3 (1966): 338-52.

US Department of Health, Education, and Welfare. Toward a Social Report. Washington, DC: US Government Printing Office, 1969. US National Commission on Law Observance and Enforcement. Report on Criminal Statistics. Washington, DC: US Government Printing Office, 1929. 
US National Commission on Law Observance and Enforcement.

Report on the Causes of Crime. Vol 1. Washington, DC: US Government Printing Office, 1929.

Weaver, Vesla M. "Frontlash: Race and the Development of Punitive Crime Policy." Studies in American Political Development 21 (2007): 230-65.

Webb, Vincent J., and Dennis E. Hoffman. "Criminal Justice as an Academic Discipline: Costs and Benefits." Journal of Criminal Justice 6 (1978): 347-55.

Wilson, James Q. “A Reader's Guide to the Crime Commission's Report." The Public Interest, no. 9 (Fall 1967): 64-82.

Wilson, James Q. Thinking about Crime. Rev. ed. New York: Basic Books, 2013.

Wilson, James Q., and Richard, J. Herrnstein. Crime and Human Nature: The Definitive Study of the Causes of Crime. New York: Simon \& Schuster, 1985.

Winant, Howard. "The Dark Side of the Force: One Hundred Years of the Sociology of Race." In Sociology in America: A History, edited by Craig Calhoun, 535-71. Chicago: University of Chicago Press, 2007.

Wolfgang, Marvin, and Franco Ferracuti. The Subculture of Violence. London: Routledge \& Kegan Paul, 1967.

Wolfgang, Marvin, Robert Figlio, and Thorsten Sellin. Delinquency in a Birth Cohort. Chicago: University of Chicago Press, 1972. 